\title{
Evaluation of Isolation Methods for Circulating Tumor Cells (CTCs)
}

\author{
Galatea Kallergia,c Eleni Politaki ${ }^{a}$ Saad Alkahtani ${ }^{\mathrm{b}, c}$ Christos Stournaras ${ }^{c}$ \\ Vassilis Georgoulias ${ }^{a}$
}

aLaboratory of Tumor Cell Biology, School of Medicine, University of Crete, Heraklion, Greece;

${ }^{b}$ Department of Zoology, Science College, King Saud University, Riyadh, Saudi Arabia; 'Department of

Biochemistry, University of Crete Medical School, Heraklion, Greece

\section{Key Words}

CTCs • Cell Search • ISET • CD45-negative selection • Breast Cancer • EpCAM-positive selection

\begin{abstract}
Background: Detection of CTCS is a poor prognostic factor for many cancer types; however, their very low frequency represents an obstacle for their detection. The objective of the current study was to compare the performance of commonly used methods for CTCs isolation. Methods: The evaluated methods using spiking experiments of MCF7, SKBR3 and MDA MB231 breast cancer cell lines were (i) ficoll density gradient separation (DGS), (ii) red blood cell lysis (Erythrolysis) isolation, (iii) positive immunomagnetic selection (EpCAM Dynal beads), (iv) two different negative immunomagnetic separation systems (Dynal vs Miltenyi CD45 beads) as well as (v) the Cell Search platform and (vi) the ISET system. Results: The recovery rates of Erythrolysis and DGS were 39\% and 24\%, respectively. Magnetic isolations are ranked from the worse to the best recovery rate as follows:, Myltenyi-anti-CD45 microbeads (24\%); Dynalanti-EpCAM beads (75\%); Dynabeads-anti-CD45 (97\%). CTCs isolation from blood samples using the CellSearch and ISET systems revealed that the recovery rate for Cell Search and ISET was 52\% and 95\%, respectively. Conclusions: Dynal-anti-CD45 beads have the best recovery rate compared to other magnetic methods. Furthermore the recovery rate of ISET was higher compared to Cell Search, especially for the more aggressive MDA-MB 231 cell line.
\end{abstract}

\section{Introduction}

Liquid biopsy is critical for the evaluation of cancer progression [1-3]. Circulating tumor cells (CTCs) are a major player in metastatic procedure and they are responsible for the hematopoietic dissemination of tumor cells [2-7]. Especially, in breast cancer, CTCs hold significant prognostic and predictive value in early disease [4, 5, 8-11]. In addition, the detection of CTCs has been shown to be an independent poor prognostic factor for prostate, colon and non small cell lung cancer [12-16]. 


\section{Cellular Physiology Cell Physiol Biochem 2016;40:411-419 \begin{tabular}{l|l|l} 
and BOI: 10.1159/000452556 & $\begin{array}{l}\text { (c) 2016 The Author(s). Published by S. Karger AG, Basel } \\
\text { www.karger.com/cpb }\end{array}$ \\
\hline
\end{tabular} \\ Kallergi et al.: Isolation Methods for CTCS}

The isolation and characterization of CTCs remains a technically challenging issue. Immunomagnetic separation is a commonly used technique. It can be applied directly to the blood or after the isolation of peripheral blood mononuclear cells (PBMCs). For positive selection the most commonly used antigen is EpCAM which is a surface protein expressed on epithelial cells; conversely, for negative selection the most commonly used antigen is CD45 which is expressed on hematopoietic cells, thus it can differentiate hematopoietic from epithelial cells. Organ specific markers such as HER2, EGFR or CEA have also been used for this purpose [17].

The CellSearch system is the only FDA approved system for the isolation and detection of CTCs' in metastatic breast, prostate and colorectal cancer [18]. This system is mainly based on immunomagnetic separation using EpCAM expression as a marker of epithelial cells despite the fact this is arguable. Indeed, it is well known that EpCAM is down regulated during Epithelial Mesenchymal Trasition (EMT) and, thus, CTCs undergoing EMT could escape EpCAM-based detection [19]. However, there are other markers like Twist, Vimentin, ALDH1 which are overexpressed in CTCs and their frequency have been recently investigated [20-23].

ISET technology is based on size filtration and recent studies have shown that it can effectively recover CTCs from different cancer types including breast, melanoma, hepatomas as well as prostate and lung cancer [24-26]. The limitation of this technology is that small tumor cells can escape isolation due to size-based filtration [24]. CTC chip as well as other filtration methods which are also based on microfiltration has been developed and can effectively isolate high numbers of circulating tumor cells $[27,28]$.

The objective of the current study was to compare the most common CTC's isolation methods using three different breast cancer cell lines representing the HER2, Luminal A and Basal like molecular subtypes of breast cancer. The use of these molecularly different cell lines was decided since there is strong evidence supporting the molecular and phenotypical heterogeneity of tumor cells that could potentially affect the isolation procedure [19]. In addition, the recovery rate of tumor cells using the Cell Search and the ISET system was also compared to other isolation systems.

\section{Materials and Methods}

\section{Cell cultures}

All cell lines were obtained from ATCC (American Type Culture Collection, USA) and used for spiking experiments. The MCF7 adenocarcinoma cells were cultured in 1:1 Dulbecco's Modified Eagle Medium (DMEM, Gluta max,) (GIBCO-BRL Co, MD, USA,) supplemented with 10\% fetal bovine serum (FBS) (GIBCOBRL), $16 \mathrm{ng} / \mathrm{ml}$ insulin and $50 \mathrm{mg} / \mathrm{ml}$ penicillin/streptomycin (GIBCO-BRL). MDA-MB-231 cells were cultured in DMEM, supplemented with $10 \%$ FBS and $50 \mathrm{mg} / \mathrm{ml}$ penicillin/streptomycin. SKBR3 cells were cultured in RPMI (GIBCO-BRL) plus 10\% FBS and 50mg/ml penicillin/streptomycin. Sub-cultivation of all cell lines was performed with $0.25 \%$ trypsin (GIBCO-BRL) and 5mM EDTA (GIBCO-BRL).

Cells were maintained in a humidified atmosphere of $5 \% \mathrm{CO}_{2}$ in air. All experiments were performed during the logarithmic growth phase of the cells.

\section{Blood samples and spiking experiments}

Different dilutions [1cell/ml, 10 cells $/ \mathrm{ml}, 100$ cells/ml and 1000 cells/ml of blood] of MCF7, SKBR3 and MDA-MB-231 cells were spiked in $10 \mathrm{ml}$ of blood obtained from healthy blood donors. All blood samples were obtained at the middle of vein puncture after the first $5 \mathrm{ml}$ of blood were discarded in order to avoid contamination of the blood sample with epithelial cells from the skin during sample collection. Ten patients with metastatic breast cancer were also enrolled in the study in order to compare the CTCs' recovery between cell lines and the patients. All patients and healthy blood donors gave their informed consent to participate in the study, which has been approved by the Ethics and Scientific Committees of our Institution. All the experiments were repeated three times. 


\section{Cellular Physiology Cell Physiol Biochem 2016;40:411-419 \begin{tabular}{ll|l} 
and Biochemistry Published online: November 25, 2016 & $\begin{array}{l}\text { (c) } 2016 \text { The Author(s). Published by S. Karger AG, Basel } \\
\text { www.karger.com/cpb }\end{array}$ \\
\hline
\end{tabular} \\ Kallergi et al.: Isolation Methods for CTCS}

Isolation of PBMCs with Ficoll density gradient

Peripheral blood mononuclear cells (PBMC) were isolated after Ficoll-Hypaque (d=1.077gr $/ \mathrm{mol}$; SIGMA, St. LOUIS, MO, USA) density gradient centrifugation at $1800 \mathrm{rpm}$ for $30 \mathrm{~min}$. PBMCs were washed three times with PBS and centrifuged at $1500 \mathrm{rpm}$ for $10 \mathrm{~min}$. Aliquots of $10^{6}$ cells were centrifuged at 2000 $\mathrm{rpm}$ for $2 \mathrm{~min}$ on glass slides. Cytospins were dried up and stored at $-80^{\circ} \mathrm{C}$ before using.

Isolation of PBMCs with Red Blood Cell Lysis

Blood samples after spiking procedure with the corresponding cell lines, were diluted 1:10 with Red Blood Cell Lysis buffer ( $0.8 \% \mathrm{NH} 4 \mathrm{Cl}, 0.1 \% \mathrm{KHCO}, 0.1 \mathrm{mM} \mathrm{EDTA})$ and agitated for $20 \mathrm{~min}$ at room temperature (RT). The samples were centrifuged at $500 \mathrm{~g}$ for $10 \mathrm{~min}$ and the pellets were rinsed three times with PBS $1 \mathrm{X}$. Aliquots of $10^{6}$ cells were centrifuged at $2000 \mathrm{rpm}$ for $2 \mathrm{~min}$ on glass slides. Cytospins were dried up and stored at $-80^{\circ} \mathrm{C}$ before using.

Positive selection of tumor cells with Dynal-anti-EpCAM beads

Tumor cells were spiked in $\left(2 \times 10^{7}\right)$ PBMCs and placed in $1 \mathrm{ml}$ buffer (PBS/0.1\% BSA, $0.6 \%$ Sodium citrate) and $50 \mu$ l of CELLection beads (Dynal, Invitrogen, Carlsbad, CA, USA) which were coated with an antiEpCAM monoclonal antibody. Supernatant was removed and $4 \mu$ l of releasing buffer in $200 \mu \mathrm{RPMI} / 1 \%$ FCS was added to the beads. After $15 \mathrm{~min}$ of incubation at room temperature, samples were placed in a magnetic device and the released cells were transferred into a different tube. Tumor cells were, subsequently, detected by double immunostaining experiments and were analyzed using the ARIOL system.

Negative selection of Tumor Cells with Dynal-anti-CD45 beads

Negative selection procedure was performed according to Naume et al [29]. Briefly, 100 $\mu$ l of CELLection beads coated with anti-CD45 monoclonal antibody (Dynal, Invitrogen, Carlsbad, CA, USA) were added in $10^{7} / \mathrm{ml}$ PBMCs in PBS $/ 0.1 \%$ BSA $/ 2 \mathrm{mM}$ EDTA. After incubation for $30 \mathrm{~min}$ at $4^{\circ} \mathrm{C}$, the supernatant was transferred in FBS-coated tubes and cells were cyto-centrifuged at 2000rpm for $2 \mathrm{~min}$ on glass slides for further double immunostaining.

Negative selection of Tumor Cells with CD45 Myltenyi-anti-CD45 beads

$10^{7}$ PBMCs spiked with tumor cells, were re-suspended in $80 \mu$ isolation buffer (PBS, 05\% BSA, $2 \mathrm{~m}$ EDTA). 20 $\mu$ l of anti-CD45-coated Miltenyi beads (Miltenyi Biotec GmbH Bergisch Gladbach, Germany) were added to the sample and the cells were incubated at $2-8^{\circ} \mathrm{C}$ for $15 \mathrm{~min} .2 \mathrm{ml}$ of the isolation buffer were added to each depletion columns in order to prepare the filters for the isolation. $400 \mu \mathrm{l}$ of the isolations buffer was also added to each sample and cells were placed onto the column. The samples were collected and the columns were washed twice with $1 \mathrm{ml}$ of the isolation buffer. The depletion fraction was centrifuged at $300 \mathrm{~g}$ for $10 \mathrm{~min}$, and cytospins were prepared for immunostaining.

ISET isolation system

Tumor cells spiked as described (dilutions of 1-100 cell/ml) in blood obtained from healthy volunteers; was diluted in 1:10 ISET buffer (RareCells, Paris, France) for 10min at RT and $10 \mathrm{ml}$ of the sample was added in each small compartment of the block and $50 \mathrm{ml}$ of the sample in the big compartment. Depression tab was $10 \mathrm{KPa}$. Blood was filtered and the membrane was removed and let it dry. The spots on the membrane were double stained with anti-CK and anti-CD45 antibodies to evaluate the recovery yield and the contamination with PBMCs.

\section{Cell Search analysis}

$7.5 \mathrm{ml}$ of blood spiked with tumor cells as above, (10, 20 and 100 cells $/ 7.5 \mathrm{ml}$ of blood) were added in CellSave Preservative Tubes (Immunicon Inc) containing EDTA and optimized cell preservative.

The samples were placed on the Cell Tracks Autoprep System. The Cell Search Circulating Tumor Cell Kit was used (Veridex Warren, NJ, USA.) containing ferrofluid particles coated with anti-EpCAM antibodies, phycoerythrin conjugated CK antibodies recognizing cytokeratins (8, 18 and/or 19) and allophycocyaninconjugated CD45 antibody, in order to identify white blood cells.

The images were presented in a gallery format which classifies the CTCs according to the Veridex's predetermined criteria. 


\section{Cellular Physiology Cell Physiol Biochem 2016;40:411-419 \begin{tabular}{ll|l} 
and BiOChemistry & $\begin{array}{l}\text { DOI: 10.1159/000452556 } \\
\text { Published online: November 25, } 2016\end{array}$ & $\begin{array}{l}\text { C } 2016 \text { The Author(s). Published by S. Karger AG, Basel } \\
\text { www.karger.com/cpb }\end{array}$ \\
\hline
\end{tabular}

\section{Double immunofluorescence}

Cytospins from the isolation experiments and from patients were fixed with cold aceton:methanol 9:1 (v/v) for 20min and stained for cytokeratin with A45-B/B3 antibody (Micromet Munich, Germany) and Alexa 488 (Invitrogen) as a secondary antibody. The pancytokeratin A45-B/B3 antibody was used as marker for epithelial cells. Consequently, slides were incubated with anti-CD45 (Santa Cruz, Santa Cruz, CA, USA), anti-rabbit antibody for $1 \mathrm{~h}$. Alexa 555 was used as a secondary antibody (Invitrogen, Carlsbad, CA, USA). Cells were then stained with DAPI (Invitrogen) conjugated with antifade. For patients' samples the cytomorphological criteria proposed by Meng et al [30] (i.e. high nuclear/cytoplasmic ratio, larger cells than white blood cells etc) were used in order to characterize a cell as CTC candidate.

\section{Results}

Ficoll density gradient centrifugation vs Red Blood Cell Lysis

The average recovery rates of Erythrolysis buffer vs DGS in MCF7 cells was 39\% (range, $32 \%-50 \%$ ) vs $25 \%$ (range, $18 \%-37 \%$ ), respectively ( $\mathrm{p}=0.044$ ); the corresponding average recovery rates for SKBR3 cells were 43\% (range, 13\%-63\%) vs 23\% (range,19\%-27\%), respectively, $(\mathrm{p}=0.034$ ) and for MDA-MB231 cells; 34\%(range, $21 \%-55 \%$ )vs 23\%(range, $21 \%-26.5 \%$ ) $(p=0.06)$, respectively, Although erythrolysis resulted in higher recovery rates in all cell lines (Fig. 1A) , the microscopic evaluation of the corresponding cytospins revealed that the cells were undamaged after Ficoll density isolation and the nucleus was more intact compared to erythrolysis buffer (Fig. 1B, C)

\section{Positive (Ep- CAM) vs Negative (CD45) magnetic isolation of tumor cells using Dynal beads}

The study of magnetic isolation of CTCs was of interest for us because it isn't a time consuming plus it's easily applied to every lab. Therefore we were initially focused to compare positive versus negative magnetic isolation in the MCF7 cell line. The comparison of different magnetic isolation techniques were evaluated after spiking different numbers of MCF7 cells in normal PBMCs as described in Materials and Methods. Positive isolation revealed an average recovery rate of $75 \%$ (range, $74 \%$ $75 \%$ ) while the negative isolation resulted in a median recovery rate of $97 \%$ (rate, $90 \%-100 \%)(p=0.01$; Table 1). Microscopic

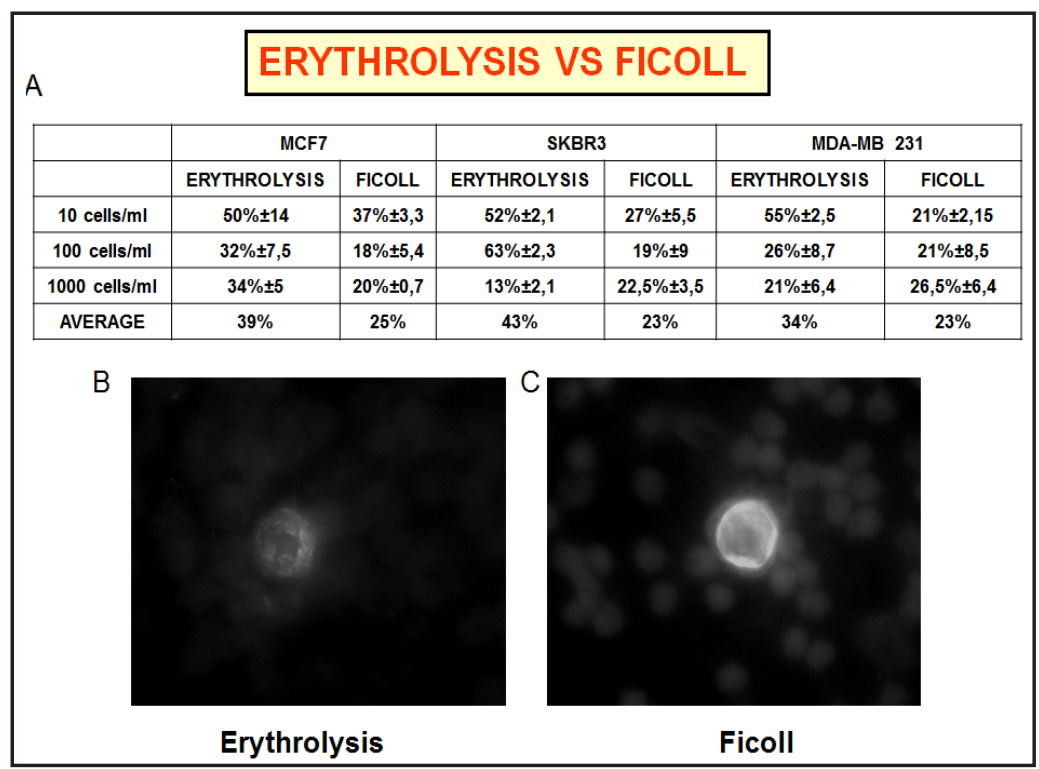

Fig. 1. Recovery of tumor cells after ficoll or erythrolysis isolation. (A) MCF7, SKBR3 and MDA-MB 231 cells were spiked in normal donors' blood at a concentration of 10, 100 and 1000 cells per ml of blood. Recovery rate \pm SE after Ficoll density gradient and Erythrolysis buffer is shown in the Table. Erythrolysis had better recovery rate in all cell lines. (B) MCF7 cell after isolation with Erythrolysis buffer. (C) MCF7 cell after isolation with Ficoll density gradient.

Table 1. Positive vs negative isolation in MCF7 cells

\begin{tabular}{lll}
\hline CELLS/PBMCs & Positive & Negative \\
\hline $10 / 106$ & $75 \%$ & $100 \%$ \\
$10^{2} / 106$ & $74 \%$ & $100 \%$ \\
$10^{3} / 106$ & $75 \%$ & $90 \%$ \\
Average & $75 \%$ & $97 \%$ \\
\hline
\end{tabular}




\section{Cellular Physiology Cell Physiol Biochem 2016;40:411-419 \begin{tabular}{l|l|l} 
and Biochemistry Published $10.1159 / 000452556$ & (c) 2016 The Author(s). Published by S. Karger AG, Basel \\
www.karger.com/cpb
\end{tabular} \\ Kallergi et al.: Isolation Methods for CTCS}

Table 2. Dynal CD45 beads vs Miltenyi CD45 microbeads

\begin{tabular}{|c|c|c|c|c|c|c|}
\hline \multirow[b]{2}{*}{ CELLS/106PBMCS } & \multicolumn{2}{|c|}{ MCF7 } & \multicolumn{2}{|c|}{ MBA-MD 231} & \multicolumn{2}{|c|}{ SKBR3 } \\
\hline & DYNAL & $\begin{array}{l}\text { MILTEN } \\
\text { YI }\end{array}$ & DYNAL & MILTENYI & DYNAL & MILTENYI \\
\hline 10/106 PBMCs & $100 \pm 0$ & $35 \pm 15$ & $100 \pm 0$ & $55 \pm 45$ & $100 \pm 0$ & $30 \pm 20$ \\
\hline $100 / 10^{6} \mathrm{PBMCs}$ & $89 \pm 9$ & $4 \pm 0$ & $83 \pm 17$ & $12 \pm 8$ & $100 \pm 0$ & $7 \pm 7$ \\
\hline Average & 94,5 & 19,5 & 91,5 & 33,5 & 100 & 18,5 \\
\hline
\end{tabular}

evaluation of the samples, using double immunofluorescence staining, also revealed that the contamination with the PBMCs was higher in the case of negative compared to positive selection. Specifically, in each examined spot the average contamination was 1.5 CTCs/100 PBMCs in negative selection vs 11.5 CTCs/100 PBMCs in positive selection experiments.

Negative magnetic isolation using Dynalanti-CD45 vs Myltenyi-anti-CD45 beads

Since negative isolation resulted in a higher recovery rate but the samples presented a higher contamination with normal PBMCs. We tried to compare two negative isolation protocols by using antiCD45-coated beads of different origin (Dynal vs Miltenyi). Table 2 shows that Dynal beads resulted in higher recovery rates, irrespectively of the molecular subtype of the used tumor cells [94.5\% (range, 89\%-100\%)
Table 3. Recovery rate after ISET isolation platform in MCF7, SKBR3 and MDA-MB 231 cells

\begin{tabular}{lllc}
\hline \multicolumn{3}{c}{ RECOVERY } \\
Cells/ml & MCF7 & SKBR3 & MDA-MB 231 \\
\hline $1 / \mathrm{ml}$ & $100 \%$ & $100 \%$ & $98 \%$ \\
$10 / \mathrm{ml}$ & $83 \%$ & $85 \%$ & $100 \%$ \\
$100 / \mathrm{ml}$ & $96,9 \%$ & $93 \%$ & $100 \%$ \\
Average & $93 \%$ & $93 \%$ & $99 \%$ \\
\hline
\end{tabular}

Table 4. Recovery rate after Cell Search isolation in MCF7 and SKBR3 cells

\begin{tabular}{lllc}
\hline & \multicolumn{3}{c}{ Recovery } \\
Cells/ml & MCF7 & SKBR3 & MDA-MB 231 \\
\hline 10 & $57,5 \%$ & $60 \%$ & $41.3 \%$ \\
20 & $79 \%$ & $50 \%$ & $44 \%$ \\
100 & $63 \%$ & $37 \%$ & $36.4 \%$ \\
Average & $66,6 \%$ & $49 \%$ & $40.6 \%$ \\
\hline
\end{tabular}
in MCF7, 91.5\% (range, 83\%-100\%) in MDA-MB 231 and 100\% (range,100\%-100\%) in SKBR3 cells]; the corresponding recovery rates for Miltenyi beads were rather low $19.5 \%$ (range, $4 \%$ to $35 \%$ ), $33.5 \%$ (range, $12 \%$ to $55 \%$ ) and $18.5 \%$ (range $100 \%$ to $100 \%$ ) $(\mathrm{p}=0.0001)$, respectively. The residual normal PBMCs' contamination was significantly lower in experiments using Miltenyi-anti-CD45 beads (median 0.5\%) compared to a median of $20 \%$ using the Dynal-anti-CD45 beads

Similar results were obtained when isolation experiments with the Myltenyi-anti-CD45 coated beads were performed using either a manual or an automated system (Auto-MACS pro-separator system) (recovery rate $19.5 \%$ and $22 \%$, respectively).

\section{Isolation experiments in patients' blood}

In order to identify if the recovery rate of negative selections in cell lines is comparable to patients' samples, indicative isolation experiments were performed using patients' blood.

Using Dynal-anti-CD45 coated beads from 4 patients with metastatic breast cancer after Ficoll density gradient centrifugation and CTCs enumeration both before and after magnetic isolation, the median positivity rate was $87 \%$ (range, 47\%-100\%). Similarly, isolation experiments were also performed using the Miltenyi-anti-CD45 coated beads in 7 patients with metastatic breast cancer and the median positivity rate was $12 \%$ (range, 1\%-100\%).

\section{ISET isolation}

Table 3 represents the recovery rates of tumor cells from the different cell lines using the ISET system; the recovery rate was 93\% for the MCF7 (range; 83\%-100\%) and SKBR3 (range; 98\%-100\%) cells and 99\% (range; 98\%-100\%) for MDA-MB 231 cells. There was no significant difference in the recovery rate of the different subtypes of breast cancer 


\section{Cellular Physiology Cell Physiol Biochem 2016;40:411-419 \\ \begin{tabular}{l|l|l} 
and Biochemistry & $\begin{array}{l}\text { DOI: 10.1159/000452556 } \\
\text { Published online: November 25, } 2016\end{array}$ & $\begin{array}{l}\text { (c) 2016 The Author(s). Published by S. Karger AG, Basel } \\
\text { www.karger.com/cpb }\end{array}$ \\
\hline
\end{tabular} \\ Kallergi et al.: Isolation Methods for CTCS}

cells according to the spiking experiments (Table 3). Microscopic evaluation of the spots revealed that the contamination with PBMCs was approximately $2000 \mathrm{PBMCs} / \mathrm{ml}$ of blood. The method was fast and the membranes were easily further evaluated by immunotsaining experiments.

\section{Cell Search isolation}

Using the CellSearch system the average recovery rate for 10, 20, 100 MCF7 cells/ml was $57.5 \%, 79 \%$ and $63 \%$, respectively. The average recovery rate in all dilutions $(66.6 \%)$ was the highest among all the examined cell lines. Regarding the SKBR3 cells, the recovery rate was $60 \%$ for the dilution of 10 cells $/ \mathrm{ml}, 50 \%$ for 20 cells $/ \mathrm{ml}$ and $37 \%$ for 100 cells $/ \mathrm{me}$. The average recovery rate was $49 \%$. The lowest recovery rate (average $40.6 \%$ ) was observed in MDA-MB 231 cells $(41.3 \%, 44 \%$ and $36.4 \%$ for the dilutions of 10 cells $/ \mathrm{ml}, 20 \mathrm{cells} / \mathrm{ml}$ and 100 cells/ml, respectively) Table 4 . We need to mention that Cell Search is a friendly to user system, however it needs extra training and at least 3 hours to start samples'evaluation.

\section{Discussion}

Clinical implication of CTCs regarding the patients' prognosis as well as different therapeutic options based on their particular phenotypic and molecular characteristics have already been reported $[2,8,11,31]$. Therefore, the effective isolation of CTCs is a really critical step for further understanding of their biological and clinical relevance; however, there is no standard methodology for this.

The current study was designed to systematically compare the most common CTCs' isolation methods directly from patients' blood, providing a useful tool for scientist in the field of liquid biopsy. For this purpose, spiking experiments using breast cancer cell lines (MCF7, SKBR3 and MDA-MB 231), which represent different molecular subtypes of the disease, were performed in order to evaluate whether the molecular subtype of the tumor cells could influence the isolation of CTCs. This is especially important, since it is well established that many CTCs loose their epithelial phenotype such as EpCAM and cytokeratin expression while up-regulate the expression of different EMT-associated antigens such as Twist and vimentin during their phase of migration in the bloodstream [19-21].

The initial comparison of Red blood cell lysis (erythrolysis) with Ficoll density gradient centrifugation, demonstrated that the higher recovery rate was observed after erythrolysis, irrespectively of the molecular subtype of tumor cells and these differences were statistically significant for MCF7 ( $p=0.044)$ and SKBR3 ( $p=0.034)$ cells. It is interesting to note that the highest recovery rate was observed in MCF7 cells compared to the two other cell lines after both Ficoll density centrifugation and erythrolysis. This could be probably attributed to the expression of various adhesion molecules and/or gene profiling that lead to differential cell contacts that can potentially influence the recovery rate [32-35]. In addition, characterizing the cells after immunofluoresence staining with pancytokeratin A45-B/B3 antibody revealed that the cells after Ficoll density gradient centrifugation displayed a morphologically better shape and the nucleus was more intact compared to erythrolysis buffer. This observation could imply that for morphological studies ficoll density gradient centrifugation is a better isolation procedure while for molecular analysis erythrolysis should be preferred.

The positive and negative selection of MCF7 using Dynal beads demonstrated that positive isolation gave an average recovery rate of $75 \%$ while for negative selection the average recovery rate was $97 \%$. These differences were statistically significant $(\mathrm{p}=0.01)$. However, the contamination with PBMCs was lower in experiments based on positive selection compared to experiments based on negative selection. This observation implies that for methods which need high purity, such as molecular assays, positive selection of CTCs would be a preferable choice; In addition comparison of two different negative selections (Dynal-antiCD45 vs Miltenyi-anti-CD45) showed that the recovery rate of Dynal beads was significantly 


\title{
Cellular Physiology Cell Physiol Biochem 2016;40:411-419

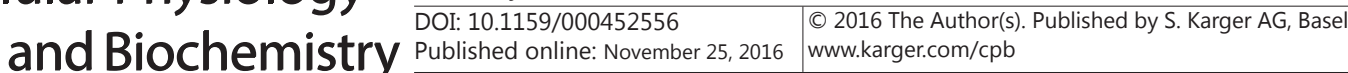 \\ Kallergi et al.: Isolation Methods for CTCS
}

higher ( $\mathrm{p}=0.0001$; Table 2), however the contamination with PBMCs was also enhanced compared to Miltenyi.

Two other commonly used methods were also evaluated in our study. The recovery rates with CellSearch system is higher for MCF7 (66.6\%) cells though there are significant loses especially for MDA-MB 231 cells (40.6\%). The lower detection of MDA-MB 231 cells could be attributing to the lower expression of EpCAM antigen compared to MCF7 cells [36, 37], since MDA-MB 231 are considered to have an Epithelial to Mesenchymal Transition (EMT) phenotype

ISET system demonstrated a very good (more than 90\%) recovery rate which was significantly higher compared with that of Cell Search system. The recovery yield obtained with the ISET platform was independent on the molecular subtype of the tumor cells. These results are in agreement with previous reports regarding recovery rates using the ISET system [38].

Several studies have also tried to address the problem of CTCs isolation in different type of cancer such as NSCLC, colon, prostate $[39,40]$. Microfiltration and negative selection have given the most interesting results in agreement with our results.

\section{Conclusion}

ISET platform and CD45 Dynal negative selection revealed the best recovery rate for CTCs. Cell Search system is more effective in EpCAM positive cell lines. Therefore molecular subtype can influence the recovery of CTCs depending on isolation method.

\begin{abstract}
Abbreviations
CTCs (Circulating Tumor Cells); PBMCs (Peripheral Blood Mononuclear Cells).
\end{abstract}

\section{Acknowledgements}

This work was partly supported by Research Grants from Hellenic Oncology Research Group (HORG), Greek General Secretary of Research and Technology grant Oncoseed PN 3175 and the International Scientific Partnership Program ISPP at King Saud University for funding this research work through (ISPP\#009).

\section{Disclosure Statement}

The authors declare that they have no competing interest

\section{References}

1 Shao Y, Geng Y, Gu W, Huang J, Ning Z, Pei H: Prognostic significance of microRNA-375 downregulation in solid tumors: a meta-analysis. Dis Markers 2014;2014:626185.

2 Yu C, Wang Z, Xu X, Xiang W, Huang X: Circulating Hepatocellular Carcinoma Cells are Characterized by CXCR4 and MMP26. Cell Physiol Biochem 2015;36:2393-2402.

3 Fan JL, Yang YF, Yuan CH, Chen H, Wang FB: Circulating Tumor Cells for Predicting the Prognostic of Patients with Hepatocellular Carcinoma: A Meta Analysis. Cell Physiol Biochem 2015;37:629-640.

4 Pantel K, Muller V, Auer M, Nusser N, Harbeck N, Braun S: Detection and clinical implications of early systemic tumor cell dissemination in breast cancer. Clin Cancer Res 2003;9:6326-6334. 


\section{Cellular Physiology Cell Physiol Biochem 2016;40:411-419 \begin{tabular}{l|l|l} 
and Biochemistry $10.1159 / 000452556$ & $\begin{array}{l}\text { DO } 2016 \text { The Author(s). Published by S. Karger AG, Basel } \\
\text { www.karger.com/cpb }\end{array}$
\end{tabular} \\ Kallergi et al.: Isolation Methods for CTCS}

5 Pantel K, Wolfle U: [Minimal residual disease in breast cancer: detection and clinical relevance]. Verh Dtsch Ges Pathol 2005;89:68-75.

6 Nguyen DB, Ly TB, Wesseling MC, Hittinger M, Torge A, Devitt A, Perrie Y, Bernhardt I: Characterization of Microvesicles Released from Human Red Blood Cells. Cell Physiol Biochem 2016;38:1085-1099.

7 Zhang J, Zhang HD, Yao YF, Zhong SL, Zhao JH, Tang JH: beta-Elemene Reverses Chemoresistance of Breast Cancer Cells by Reducing Resistance Transmission via Exosomes. Cell Physiol Biochem 2015;36:22742286.

8 Cristofanilli M, Hayes DF, Budd GT, Ellis MJ, Stopeck A, Reuben JM, Doyle GV, Matera J, Allard WJ, Miller MC, Fritsche HA, Hortobagyi GN, Terstappen LW: Circulating tumor cells: a novel prognostic factor for newly diagnosed metastatic breast cancer. J Cin Oncol 2005;23:1420-1430.

9 Ignatiadis M, Xenidis N, Perraki M, Apostolaki S, Politaki E, Kafousi M, Stathopoulos EN, Stathopoulou A, Lianidou E, Chlouverakis G, Sotiriou C, Georgoulias V, Mavroudis D: Different prognostic value of cytokeratin-19 mRNA positive circulating tumor cells according to estrogen receptor and HER2 status in early-stage breast cancer. J Clin Oncol 2007;25:5194-5202.

10 Stathopoulou A, Gizi A, Perraki M, Apostolaki S, Malamos N, Mavroudis D, Georgoulias V, Lianidou ES: Realtime quantification of CK-19 mRNA-positive cells in peripheral blood of breast cancer patients using the lightcycler system. Clin Cancer Res 2003;9:5145-5151.

11 Xenidis N, Perraki M, Kafousi M, Apostolaki S, Bolonaki I, Stathopoulou A, Kalbakis K, Androulakis N, Kouroussis C, Pallis T, Christophylakis C, Argyraki K, Lianidou ES, Stathopoulos S, Georgoulias V, Mavroudis D: Predictive and prognostic value of peripheral blood cytokeratin-19 mRNA-positive cells detected by real-time polymerase chain reaction in node-negative breast cancer patients. J Clin Oncol 2006;24:37563762.

12 Wang J, Wang K, Xu J, Huang J, Zhang T: Prognostic significance of circulating tumor cells in non-small-cell lung cancer patients: a meta-analysis. PloS one 2013;8:e78070.

13 Lu CY, Uen YH, Tsai HL, Chuang SC, Hou MF, Wu DC, Juo SH, Lin SR, Wang JY: Molecular detection of persistent postoperative circulating tumour cells in stages II and III colon cancer patients via multiple blood sampling: prognostic significance of detection for early relapse. Br J Cancer 2011;104:1178-1184.

14 Uen YH, Lin SR, Wu DC, Su YC, Wu JY, Cheng TL, Chi CW, Wang JY: Prognostic significance of multiple molecular markers for patients with stage II colorectal cancer undergoing curative resection. Ann Surg 2007;246:1040-1046.

15 Allard WJ, Matera J, Miller MC, Repollet M, Connelly MC, Rao C, Tibbe AG, Uhr JW, Terstappen LW: Tumor cells circulate in the peripheral blood of all major carcinomas but not in healthy subjects or patients with nonmalignant diseases. Clin Cancer Res 2004;10:6897-6904.

16 de Bono JS, Scher HI, Montgomery RB, Parker C, Miller MC, Tissing H, Doyle GV, Terstappen LW, Pienta KJ, Raghavan D: Circulating tumor cells predict survival benefit from treatment in metastatic castration-resistant prostate cancer. Clin Cancer Res 2008;14:6302-6309.

17 Gerges N, Rak J, Jabado N: New technologies for the detection of circulating tumour cells. Br Med Bull 2010;94:49-64.

18 Miller MC, Doyle GV, Terstappen LW: Significance of Circulating Tumor Cells Detected by the CellSearch System in Patients with Metastatic Breast Colorectal and Prostate Cancer. J Oncol 2010;2010:617421.

19 Sieuwerts AM, Kraan J, Bolt J, van der Spoel P, Elstrodt F, Schutte M, Martens JW, Gratama JW, Sleijfer S, Foekens JA: Anti-epithelial cell adhesion molecule antibodies and the detection of circulating normal-like breast tumor cells. J Natl Cancer Inst 2009;101:61-66.

20 Aktas B, Tewes M, Fehm T, Hauch S, Kimmig R, Kasimir-Bauer S: Stem cell and epithelial-mesenchymal transition markers are frequently overexpressed in circulating tumor cells of metastatic breast cancer patients. Breast Cancer Res 2009;11:R46.

21 Kallergi G, Papadaki MA, Politaki E, Mavroudis D, Georgoulias V, Agelaki S: Epithelial to mesenchymal transition markers expressed in circulating tumour cells of early and metastatic breast cancer patients. Breast Cancer Res 2011;13:R59.

22 Kasimir-Bauer S, Hoffmann O, Wallwiener D, Kimmig R, Fehm T: Expression of stem cell and epithelialmesenchymal transition markers in primary breast cancer patients with circulating tumor cells. Breast Cancer Res 2012;14:R15. 


\section{Cellular Physiology Cell Physiol Biochem 2016;40:411-419 and Biochemistry Published online: November 25, 2016 \begin{tabular}{l|l} 
DOI: 10.1159/000452556 2016 The Author(s). Published by S. Karger AG, Basel \\
www.karger.com/cpb
\end{tabular} \\ Kallergi et al.: Isolation Methods for CTCS}

23 Theodoropoulos PA, Polioudaki H, Agelaki S, Kallergi G, Saridaki Z, Mavroudis D, Georgoulias V: Circulating tumor cells with a putative stem cell phenotype in peripheral blood of patients with breast cancer. Cancer Let 2010;288:99-106.

24 Farace F, Massard C, Vimond N, Drusch F, Jacques N, Billiot F, Laplanche A, Chauchereau A, Lacroix L, Planchard D, Le Moulec S, Andre F, Fizazi K, Soria JC, Vielh P: A direct comparison of CellSearch and ISET for circulating tumour-cell detection in patients with metastatic carcinomas. Br J Cancer 2011;105:847853.

25 Mazzini C, Pinzani P, Salvianti F, Scatena C, Paglierani M, Ucci F, Pazzagli M, Massi D: Circulating tumor cells detection and counting in uveal melanomas by a filtration-based method. Cancers 2014;6:323-332.

26 Morris KL, Tugwood JD, Khoja L, Lancashire M, Sloane R, Burt D, Shenjere P, Zhou C, Hodgson C, Ohtomo T, Katoh A, Ishiguro T, Valle JW, Dive C: Circulating biomarkers in hepatocellular carcinoma. Cancer Chemother Pharmacol 2014;74:323-332.

27 Nagrath S, Sequist LV, Maheswaran S, Bell DW, Irimia D, Ulkus L, Smith MR, Kwak EL, Digumarthy S, Muzikansky A, Ryan P, Balis UJ, Tompkins RG, Haber DA, Toner M: Isolation of rare circulating tumour cells in cancer patients by microchip technology. Nature 2007;450:1235-1239.

28 Adams DL, Stefansson S, Haudenschild C, Martin SS, Charpentier M, Chumsri S, Cristofanilli M, Tang CM, Alpaugh RK: Cytometric characterization of circulating tumor cells captured by microfiltration and their correlation to the CellSearch((R)) CTC test. Cytometry A 2015;87:137-144.

29 Naume B, Borgen E, Nesland JM, Beiske K, Gilen E, Renolen A, Ravnas G, Qvist H, Karesen R, Kvalheim G: Increased sensitivity for detection of micrometastases in bone-marrow/peripheral-blood stem-cell products from breast-cancer patients by negative immunomagnetic separation. Int J Cancer 1998;78:556-560.

30 Meng S, Tripathy D, Frenkel EP, Shete S, Naftalis EZ, Huth JF, Beitsch PD, Leitch M, Hoover S, Euhus D, Haley B, Morrison L, Fleming TP, Herlyn D, Terstappen LW, Fehm T, Tucker TF, Lane N, Wang J, Uhr JW: Circulating tumor cells in patients with breast cancer dormancy. Clin Cancer Res 2004;10:8152-8162.

31 Georgoulias V, Bozionelou V, Agelaki S, Perraki M, Apostolaki S, Kallergi G, Kalbakis K, Xyrafas A, Mavroudis D: Trastuzumab decreases the incidence of clinical relapses in patients with early breast cancer presenting chemotherapy-resistant CK-19mRNA-positive circulating tumor cells: results of a randomized phase II study. Ann Oncology 2012;23:1744-1750.

32 Kenny PA, Lee GY, Myers CA, Neve RM, Semeiks JR, Spellman PT, Lorenz K, Lee EH, Barcellos-Hoff MH, Petersen OW, Gray JW, Bissell MJ: The morphologies of breast cancer cell lines in three-dimensional assays correlate with their profiles of gene expression. Mol Oncol 2007;1:84-96.

33 Holliday DL, Speirs V: Choosing the right cell line for breast cancer research. Breast Cancer Res 2011;13:215.

34 Nadal-Serrano M, Sastre-Serra J, Valle A, Roca P, Oliver J: Chronic-leptin attenuates Cisplatin cytotoxicity in MCF-7 breast cancer cell line. Cell Physiol Biochem 2015;36:221-232.

35 Valle A, Sastre-Serra J, Oliver J, Roca P: Chronic leptin treatment sensitizes MCF-7 breast cancer cells to estrogen. Cell Physiol Biochem 2011;28:823-832.

36 Martowicz A, Spizzo G, Gastl G, Untergasser G: Phenotype-dependent effects of EpCAM expression on growth and invasion of human breast cancer cell lines. BMC Cancer 2012;12:501.

37 Stojanovic I, Schasfoort RB, Terstappen LW: Analysis of cell surface antigens by Surface Plasmon Resonance imaging. Biosens Bioelectron 2014;52:36-43.

38 Vona G, Sabile A, Louha M, Sitruk V, Romana S, Schutze K, Capron F, Franco D, Pazzagli M, Vekemans M, Lacour B, Brechot C, Paterlini-Brechot P: Isolation by size of epithelial tumor cells : a new method for the immunomorphological and molecular characterization of circulatingtumor cells. Am J Pathol 2000;156:5763.

39 Wu S, Liu Z, Liu S, Lin L, Yang W, Xu J: Enrichment and enumeration of circulating tumor cells by efficient depletion of leukocyte fractions. Clin Chem Lab Med 2014;52:243-251.

40 Pailler E, Oulhen M, Billiot F, Galland A, Auger N, Faugeroux V, Laplace-Builhe C, Besse B, Loriot Y, NgoCamus M, Hemanda M, Lindsay CR, Soria JC, Vielh P, Farace F: Method for semi-automated microscopy of filtration-enriched circulating tumor cells. BMC cancer 2016;16:477. 